\title{
Influence of Working Capital Metrics on Profitability: A Critical Examination on Indian Manufacturing Sector
}

\author{
M. Aravind \\ TKM Institute of Management, Kerala, India \\ (E-Mail: aravind.1551@gmail.com)
}

\begin{abstract}
The disbursement of working capital is usually considered as a short term cash flow and it is totally neglected by the policy makers to tag with profitability of a concern. Usually the variation in working capital will be observed at the end of the financial year. Such observations will be just a postmortem of financial events happened. Various metrics like Cash Conversion Cycle (CCC), Net Trade Cycle etc directly or indirectly controlling profitability of business. This work investigates how various working capital metrics influencing profitability of the firms by observing a data set of 100 manufacturing companies in India. This study comprehends ten year financial data from the FY 2005-06 to the FY 2014-15. All together a balanced panel set of 1000 firm-year observations form part of this research. The data analysis was carried out using both descriptive and inferential statistical measures. The results show that CCC is positively correlated to Net profit Ratio (NPR) but negatively related to the Return on Equity (ROE). Another major fact identified that the Indian manufacturing firms are having a high DPO (Days Payable Outstanding) while maintaining a moderate DSO (Days Sales Outstanding) and DIO (Days Inventory Outstanding). This situation spots towards the fact that the manufacturing firms are enjoying liberal credit policy from their suppliers. The study also looks into the impact of working capital on profitability at distinct economic phases. The result concludes that the influence of working capital on profitability was consistent irrespective of the economic cycle.
\end{abstract}

Keywords: Cash Conversion Cycle, Net Trade Cycle, Profitability Measures

\section{Introduction}

Working capital management in general will deals with how a firm is carrying out their day to day activities with the money that they have. The requirement of working capital may vary depending upon the nature of the firm. While considering the requirement of working capital; a firm should avoid two danger levels viz. excessive working capital and inadequate working capital. The excessive working capital will impair firm's profitability and inadequate working capital threatens solvency of the firm. Anyway it is mandatory that the firm should buffer sufficient amount of liquid 
cash to mature their obligations. In the practical scenario firms are more concerned about generating adequate return on their investment in fixed assets, but none of them taking sincere effort to tag firm's performance in connection with working capital. The investment in working capital will be turned over many times in a year; however the investment in fixed assets will be turned only after a few years. In due respect to the above the policy makers have to devote sufficient time for finding a linkage with working capital on profitability. This research work look in to how working capital can influence on profitability of the business. In order to have an in-depth evaluation on the scenario different working capital metrics were used in the study. Some key metric used for the evaluation are Cash Conversion Cycle (CCC) and Net Trade Cycle (NTC). Cash conversion cycle is the time period for converting firm's activities in to cash and net trade cycle express different components of cash conversion cycle as a percentage to sales. The relation of such working capital metrics on various profitability measures like Net Profit Ratio (NPR), Return on Equity (ROE) and Return on Assets (ROA) were examined.

In India the contribution of manufacturing sector to GDP is stagnated around 15\%$16 \%$ for several years. In a report published by PWC (2014) states that with the advent of make in India campaign the contribution of manufacturing sector expected to reach $25 \%$ of the GDP by 2020 . According to the estimations in this report we can expect a boom in manufacturing sector. As far as manufacturing industries are concerned; the cash conversion cycle is expected to be lengthy as it involves various stages like procurement of raw materials, manufacturing finished goods, sale of finished products and collection of dues from debtors etc. Such lengthy operating cycle may hamper the liquidity and profitability position of such firms. Here some interesting questions can be asked such as whether the operating cycle span can influence firm's profitability or is it possible to enhance profitability of a firm by curbing their cash conversion cycle. With due respect to the above questions it is quite interesting to have an examination on the influence of various working capital standards on profitability of the firm. In this research I made a sincere effort to address the above questions by examining the financial data of 100 Indian manufacturing firms from the FY 2005-06 to the FY 2014-15.

\section{Working Capital on Profitability: Empirical Evidences}

An extensive review of available literature was done in order to understand how working capital is influencing the profitability of business concerns. Deloof (2003) says that managing working capital have a significant influence on the profitability. After conducting a research on 1009 Belgium firms over 1992-96 period; he concludes that there exist a significant negative relation between gross operating income and the number of days accounts receivable, inventories and accounts payable 
of Belgium firms. He also suggests that the managers should reduce the number of days account receivables and inventories in order to attain a better stage of profitability. Gill (2010) found a statistically significant relationship between cash conversion cycle and profitability. For this a sample of 88 firms listed in New York stock exchange were collected. The data so collected were evaluated by using different statistical measures like Pearson's correlation, linear regression etc. Mohamad (2010) randomly selected 172 listed companies in Malaysia for analyzing the effect of working capital on profitability. Applying correlations and multiple regression analysis, the result shows that there are significant negative associations between working capital variables with firm's performance.

Sharma and Kumar (2011) analyzed a sample of 263 non-financial firms listed with BSE 500. The study period covered from 2000 to 2008. The collected data was analyzed by using OLS Regression method. They found a positive correlation between day's accounts receivable and cash conversion cycle with profitability while days accounts payable possess a negative connection with profitability. A study conducted by Qazi (2011) wrap up with a conclusion that various independent metrics like networking capital, inventory turnover in days, average account receivable and financial asset to total assets can positively influence profitability of a firm. Afeef (2011) also came up with a similar line of finding for his study conducted among Small and Medium Enterprises in Pakistan. In another study Bieniasz and Golas (2011) examines the influence of working capital management on food enterprises profitability at selected countries in Euro zone. They conclude that the food industry is obtaining highest profitability on account of shortest working capital cycle. Quayyam (2011) reveals that there exist a positive correlation between management of working capital and liquidity and profitability of a concern. He arrived at this conclusion based on a study conducted with enlisted cement companies in Dhaka stock exchange. Rahman (2011) look in to the impact of working capital on profitability with reference to textile industry in Bangladesh The study reveals that the relationship between working capital and profitability of textile industry is not satisfactory. The author also favors that the efficient management of working capital can influence profitability of a firm. In another study after evaluating 16 Brazilian listed companies of various dimensions Ching (2011); concludes that regardless type of the enterprise managing working capital is equally important.

Vural (2012) investigates the relationship between working capital management and firm's performance by evaluating the financial data of 75 manufacturing firms listed with Istanbul stock exchange. The study results show that the firm can increase their profitability by curbing their cash conversion cycle. In order to reduce the cash conversion cycle they suggest that the firm have to shorten their collection period of accounts receivables. Bagchi and Khamrui (2012) had done a research on working 
capital management on profitability in the context of FMCG companies in India. They have taken ten companies from FMCG sector and financial data for a period of ten years from 2000-01 to 2009-10 were used. Interestingly the study results claims that there exist a strong negative relationship between variables of the working capital management and profitability of the firm. Abuzayed (2012) explicate the relationship between working capital management and firm's profitability of companies listed with Amman stock exchange. To bring up more robust results, this study used more than one estimation technique, including panel data analysis, fixed and random effects, and generalized methods of moments. The study winds up with a conclusion that there exist a positive relation between working capital and profitability. Ray (2012) tries to explore the relationship between working capital management components and the profitability of Indian manufacturing firms by using a sample of 311Indian manufacturing firms for a period of 14 years from 1996-97 to 2009-10. The result suggests a strong negative relationship between the measures of working capital management including the number of days accounts receivable and cash conversion cycle, financial debt ratio with corporate profitability.

Khanqah (2012) says the increase in Collection Period, Payment Period, and Net Trading will lead towards the reduction of profitability in the firm. In other words, managers can increase the profitability of their firms reasonably, by reducing Collection Period, Inventory Turnover, and Payment Period. A study conducted in Thailand stock exchange with a sample of 255 companies by Napompech (2012) explicates a negative relation between operating profit with inventory conversion period and debtor's collection period. These results were obtained based on regression analysis done on panel data samples. In another extend a study conducted by Joyce (2012) on non-deposit taking micro financing institutions in Kenya collected data from 63 staff members working in such institutions. The study was intended to analyze the influence of WCM on profitability. The primary data collected were analyzed by using both descriptive and inferential statistical tools. The findings indicated that, there exists a very strong, statistically significant and positive correlation between cash management and profitability of non-deposit-taking MFIs in the region.

Nzioki (2013) analyzed the effects of working capital management on the profitability of manufacturing firms listed on the Nairobi Securities Exchange. The results from the study revealed that gross operating profit was positively correlated with average collection period and average payment period but negatively correlated with cash conversion cycle. A study by Akoto (2013) signifies that firms' cash conversion cycle, current asset ratio, size, and current asset turnover can positively influence profitability. Whereas it found that there exists negative relationship between profitability and accounts receivable days. These results were obtained on 
the basis of data collected from all the 13 listed manufacturing firms in Ghana covering the period from 2005 to 2009. Aregbeyen (2013) investigates the effects of working capital management on the profitability of a sample of 48 large manufacturing firms quoted on the Nigerian Stock Exchange (NSE) for the period 1993 to 2005 . He concludes that in order to improve the efficiency; the firms will have to shorten cash conversion cycle and average collection period. Makori (2013) used Pearson's correlation and ordinary least squares regression models were used to establish the relationship between working capital management and firm's profitability. These tools were used to analyze the balanced panel data of five manufacturing and construction firms each which are listed on the Nairobi Securities Exchange. The study find a negative relation between profitability and cash conversion cycle and a positive relation between profitability and number of days of inventory and number of day's payable. Knauer (2013) says management of accounts receivables and inventory can have a positive effect on profitability. However there exist a reverse association between accounts payable and profitability.

Working capital variables like accounts receivable turnover, creditor's turnover, inventory turnover etc. have a significant impact on firm's profitability. So the firm will have to reduce accounts receivable turnover, creditor's turnover, inventory turnover etc. to improve their profitability says Agha (2014).

\section{Management of Working Capital in Various Economic Phases}

Before the wake of the global recession, working capital management has been an important subject matter to ensuring the stability and hence the survival of a business and after the economic meltdown it became much more important says Ikpefan (2014).

Kesimli (2011) studies the impact of the global economic crisis on the working capital of real sector in Turkey. They have analyzed the working capital position of Turkish real sector firms based on financial statements. Pre-crisis era has been compared with the crisis era and the results of this study draw conclusions that the profitability of 45 ISE companies, chosen among others, has been affected on a limited basis during crisis period.

Baveld (2012) investigates how public listed firms in The Netherlands manage their working capital. A sample of 37 firms is used and the working capital policies during the non-crisis period of 2004-2006 and during the financial crisis of 2008 and 2009 are compared. This comparison investigates whether companies have to change their non-crisis working capital policies when the economy is into a recession. The results of this study indicate that, in crisis periods, firms don't need to change their working 
capital policy concerning accounts payables and inventory, if their goal is to enhance profit.

Duggal (2012) says many firms have changed their inventory, accounts receivable, and/or accounts payable policies, causing the firms to use more/less net working capital to address economic recession. Taking a sample of non-financial S\&P 500 firms, the study finds significant changes in the cash conversion cycle in 2010 for some industries. Also, it appears firms in general held more net working capital in order to face new economic challenges.

Wasiuzzaman (2013) examined determinants of working capital investment on Malaysian publically listed firms. The identified economic cycle as one of the key impact which influence working capital requirement of the firm. They says that abundance of funds during economic boom periods will not be a cause for worry and firms will thus not be too concerned about their level of working capital, but during recession periods, as much money as possible needs to be squeezed out and the easiest way is through working capital improvements.

In another study Enqvist (2014) observes the impact of working capital management on profitability of a firm at different business cycles. They used 14 years of data of Finnish companies as sample. The research work found that the receivables conversion period and inventory conversion period significantly increased during the period of economic downtowns.

Singhania (2014) made an attempt to understand the impact of the global macroeconomic conditions on this relationship. The outcome of the study reveals that working capital strategies should be formulated taking global macroeconomic conditions into consideration.

A study conducted among 57 Malaysian firms by Haron (2015) found that four out of the six explanatory variables have significant relationships with WCM before the crisis. These factors are profitability, debt, sales growth and firm size. It is interesting to note that the same variables have significant relationships with WCM as well after the crisis of 2008. In contrast, it was found that profitability, firm size and free cash flow are significantly affecting WCM during the financial crisis of 2008

Nasrin, (2016) analyzed the impact of working capital on profitability in business cycles by examining 120 firms listed with Tehran Stock exchange. The multivariate regression result shows that there is negative relationship between cash conversion cycle and profitability of the firms. Also, it was found that the impact of business cycles on the relationship between working capital and profitability during recession periods is relatively higher, compared with boom periods. 
VU and Phan (2016) provide experimental evidence from Vietnam to confirm the important role of working capital management that has direct effect on profitability of firms. They suggest that particularly in financial crisis, the firms should accord a special attention for solution concerning to receivables collection period by justifying the leverage and current ratio at a reasonable level and also should take measures to enhance their turnover to stabilize the firm.

\section{Research Gap}

The literature survey really helps to understand the well-established relation between working capital and profitability. The survey is also intended to inspect the impact of working capital management on firm's performance at district stages of economy. All the above studies were conducted by using different data set belonging to different period in various nations. In an emerging economy like India such line of thinking can make a significant impact on the performance of manufacturing sector. In this context it is quite interesting to examine how working capital cycle can influence profitability of manufacturing sector in India. Though several studies conducted internationally to tap the relation between working capital and profitability; a detailed examination in this track is lacking in Indian context. This gap really motivated to form this research topic. Moreover the literatures related to impact of operating cycle on the profitability during various economic phases were examined. It found that some researchers are on the opinion that the firms have to form different policies during various economic phases and others are on the opinion that a stable working capital policy has to be formulated for accommodating different economic situation. Considering the above viewpoints an interesting research question can be formulated as 'Is it necessary to have different working capital policies during various economic phases?' To arrive at a self-conclusion, this question has included as a research objective.

\section{Objectives}

i. To study the influence of various working capital metrics on profitability of manufacturing sector in India.

ii. To bring out a comparison on the swing of profitability based on Cash Conversion Cycle (CCC) and Net Trade Cycle (NTC) on various subsectors.

iii. To evaluate the impact of operating cycle on firms profitability during distinct phases of economy.

\section{Hypotheses}

$\mathbf{H}_{1}$ : Cash conversion cycle cannot make any significant difference on profitability across sampled subsectors. 
$\mathbf{H}_{2}$ : Net trade cycle cannot make any significant difference on profitability across sampled subsectors.

$\mathbf{H}_{3}$ : Operating cycle has no significant influence on profitability at distinct phase of economy.

\section{Study Sample}

Simple random sampling techniques were used and only those companies listed with The National Stock Exchange of India were considered. From the source list companies from ten subsectors were considered for the study viz. FMCG, Sugar, Chemical, Cement, Pharmaceutical, Paint, Textile, Auto, Energy and Metal. Initially a sample of 125 companies was considered and the companies those who do not have a track record for ten years or more were eliminated from the list. Finally the financial data of 107 companies retained. Using 'excel rand' function seven more companies were excluded to round off the sample size to 100 . The study period extensively covers ten years from the FY 2005-06 to the FY 2014-15. As a result a balanced panel set of $1000(100 * 10)$ firm- year observations were considered for the final study. Figure 1 will explain the sector wise composition of the sampled data.

\section{Figure 01: Data sample- Sector wise compositon}

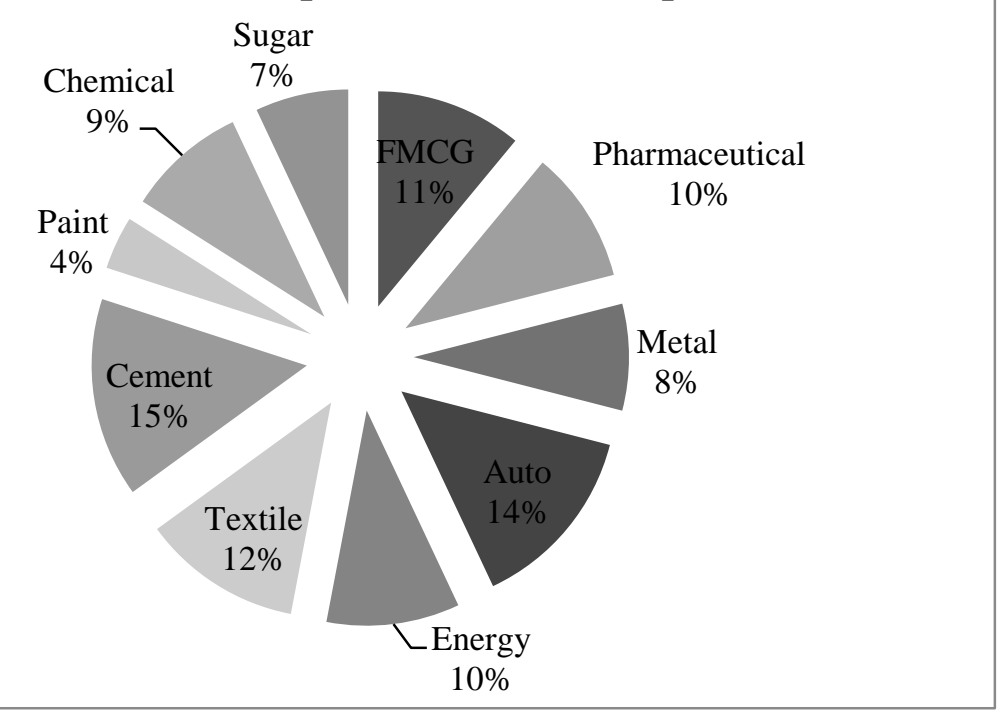

Source: Survey Data

\section{Methodology}

The collected data were analyzed by using different working capital metrics, profitability measures, descriptive and inferential statistical tools. Initially the 
collected data were worked out with the following working capital metrics and profitability measures.

a) Days Sale Outstanding (DSO): This is a measure used to identify the number of days of credit given to the customers.

$\mathrm{DSO}=(\text { Average Accounts Receivables / Net Sales })^{*} 365$

b) Days Payable Outstanding (DPO): This ratio will help to determine the number of days of credit given by the supplier to the firm.

$\mathrm{DPO}=($ Average Accounts Payable $/$ Cost of Goods Sold $) * 365$

c) Days Inventory Outstanding (DIO): This is a tool used for identifying the days will be taken to realize cash from inventory.

$\mathrm{DIO}=($ Average inventory $/$ Cost of Goods Sold $) * 365$

d) Cash Conversion Cycle (CCC): A metric for identifying how many days it takes for the company to receive cash after initial cash outlay.

$\mathrm{CCC}=\mathrm{DSO}+\mathrm{DIO}-\mathrm{DPO}$

e) Net Trade Cycle (NTC): A tool for measuring the days' worth of sales of the company has to finance.

NTC $=($ Net Sales/Net Working Capital $) / 365$

f) Net Profit Ratio (NPR): Net Profit ratio evaluates the profitability of the business via its turnover.

NPR $=($ Net Profit/Sales $) * 100$

g) Return on Assets: it is used to identify the total return generated by a firm out of its investment in assets.

$\mathrm{ROA}=($ Net Income/ Total Assets $)$

h) Return on Equity: it analyzes the return generate by the firm out of owners fund.

$\mathrm{ROE}=($ Net income/ Net worth $)$ 
Initially subsector wise pools of the sampled companies were created. This was done with the intention of providing more authentic and bifurcated study results. Both descriptive as well as inferential statistical tools were used. For examining the strength of relationship between variables Karl Pearson's correlation technique were used. Further extend of these relations were statistically examined by means of regression analysis. ' $F$ ' circuit was used to check the significance of the regression values. This model was an extension of the methodology employed by Gill (2010), Mohammed (2010), Sharma (2012) and Makori (2013). They used Pearson's correlation technique and ordinary least squares regression models to establish the relationship between working capital management and firm's profitability.

\section{Empirical Analysis and Discussion}

Descriptive statistical measures were used to scrutinize the data in the initial phase. Table 1 will provide the descriptive statistics of the whole sampled companies during the entire study period.

Table 01: Descriptive statistics of the whole samples

\begin{tabular}{|c|c|c|c|c|c|c|}
\hline Metrics & $N$ & Mean & $S D$ & Minimum & Maximum & $S E$ \\
\hline $\begin{array}{l}\text { Days Sales } \\
\text { Outstanding } \\
\text { (DSO) } \\
\text { Days Inventory }\end{array}$ & 1000 & 107.08 & 646.72 & 0.56 & 6494.73 & 64.19 \\
\hline $\begin{array}{l}\text { Outstanding } \\
\text { (DIO) } \\
\text { Days Payable }\end{array}$ & 1000 & 136.94 & 276.14 & 9.21 & 2713.93 & 27.61 \\
\hline $\begin{array}{l}\text { Outstanding } \\
\text { (DPO) } \\
\text { Cash Conversion }\end{array}$ & 1000 & 287.28 & 1265.67 & 0.00 & 11091.97 & 126.57 \\
\hline $\begin{array}{l}\text { Cycle }(\mathbf{C C C}) \\
\text { Net Trade Cycle }\end{array}$ & 1000 & -108.17 & 1303.01 & -10993.23 & 2551.45 & 130.30 \\
\hline $\begin{array}{l}\text { (NTC) } \\
\text { Return on Assets }\end{array}$ & 1000 & 0.00 & 0.01 & -0.02 & 0.05 & 0.00 \\
\hline $\begin{array}{l}\text { (ROA) } \\
\text { Return on }\end{array}$ & 1000 & 0.14 & 0.17 & -0.39 & 0.98 & 0.02 \\
\hline $\begin{array}{l}\text { Equity (ROE) } \\
\text { Net Profit Ratio }\end{array}$ & 1000 & 0.10 & 0.88 & -8.38 & 1.00 & 0.09 \\
\hline (NPR) & 1000 & 43.60 & 402.06 & -1505.33 & 3224.33 & 40.21 \\
\hline
\end{tabular}

The sampled companies maintained an average DSO period of 107.08days with a standard deviation of 646.72. Out of all observations a maximum DSO period of 6494.73 days reported, which is considered to be much higher than that of the overall standards. Average stock turnover period is 136.94 days during the study time with a deviation of 276.14. The average DPO for the whole samples reported to be 287.28 
days; which means that the companies are getting lenient credit from their suppliers while following a stringent terms and conditions regarding granting credit to their customers. As expected a negative figure of -108.17 obtained as CCC period for the whole samples. This negative value obtained on account of liberal credit facility available to companies from the suppliers. At the same time out of all observations a maximum CCC period of 2551.45 days reported. The trade cycle is close to zero line and which shows that the firms may not have the threat of financing their sales.

While analyzing the profitability measures it is observed that the companies are generating positive returns during the study period. The whole time average value of ROA is $14 \%$, ROE is $10 \%$ and that of NPR is $43.60 \%$. Out of which the standard deviation with respect to ROA is quite marginal to the extent of $17 \%$. From the whole samples maximum profitability obtained in terms of ROA is $98 \%$, ROE is $100 \%$ and that of NPR is $3224.3 \%$.

Table 02 exhibits the correlation between various working capital metrics and profitability measures during the study period.

\begin{tabular}{|c|c|c|c|c|c|c|c|c|}
\hline & DSO & DIO & DPO & $C C C$ & NTC & $R O A$ & ROE & $N P R$ \\
\hline DSO & 1.000 & -0.060 & 0.110 & 0.170 & -0.090 & -0.220 & 0.140 & 0.510 \\
\hline DIO & & 1.000 & -0.310 & 0.470 & -0.190 & -0.570 & -0.360 & -0.040 \\
\hline DPO & & & 1.000 & -0.940 & -0.270 & -0.200 & 0.100 & 0.050 \\
\hline$C C C$ & & & & 1.000 & 0.180 & 0.000 & -0.120 & 0.090 \\
\hline NTC & & & & & 1.000 & 0.750 & 0.350 & -0.120 \\
\hline ROA & & & & & & 1.000 & 0.580 & 0.050 \\
\hline ROE & & & & & & & 1.000 & 0.130 \\
\hline$N P R$ & & & & & & & & 1.000 \\
\hline
\end{tabular}

Source: Data Analysis

Karl Parsons (1948) correlation analysis is useful to quantify the strength of linear relationship between variables. In this work Pearson's correlation techniques were used for analyzing how various working capital metrics are related to the profitability measures. In due respect to the results CCC possess a negative relationship with ROE as a negative correlation result of -0.12 was obtained. It indicates that when CCC increases the ROE will decrease and vice versa. This result signifies the relation between working capital and profitability. ROE denotes return on equity and the equity shareholders are looking for early return on their investment. If CCC is lengthy it will adversely affect their objective of early return on investment. In contrary NPR shows a positive correlation with CCC as Pearson's correlation value is 0.09 . NPR 
usually tagged with sales and net sales can be increased only with a lengthy CCC. So it is quite obvious that if CCC is lengthy the firm can boost up their sales. From this we can arrive at a conclusion that $\mathrm{CCC}$ has a significant influence on profitability.

Another interesting fact is that DSO and DPO possess a positive relation with NPR \& ROE. But DIO possess a negative correlation with various profitability measures. This will partially agree with the findings of Sharma and Kumar (2011), Quasi (2011) and Afeef (2011). It signals that management of receivables and payables have a significant influence of the profitability of the firm. Likewise the negative correlation value between DIO and profitability measures indicates that the inventory conversion period and profitability aspects are moving on an opposite direction. If inventory conversion period is lengthy it will adversely affect profit. These results contributes to the existing literature of Deloof (2003), Mohammed (2010), Gill (2010) as they found a negative correlation with DIO and various profitability measures. But this analysis challenging the existing literature as the study shows no correlation between ROA and CCC.

While observing NTC, positive correlation values of 0.75 and 0.35 obtained respectively against various profitability measures ROA and ROE. But a negative figure of -0.12 reported for the correlation status between NTC and NPR. It is understandable that the variables NTC and NPR moves on an opposite direction as low NTC will be obtained at minimum turnover. Whereas NPR measures profitability and can be maximized by enhancing sales volume. So this negative relation signifies that NTC have a direct influence on various profitability measures of the sampled firms. 


\section{Influence of CCC \& NTC on Profitability: Subsector Wise Evaluation}

The influence of CCC and NTC on profitability measures were evaluated by using regression model. Regression analysis is used to understand which among the independent variables are related to the dependent variable, and to explore the forms of these relationships. Here a panel data set spread from the FY 2005-06 to 2014-15 were analyzed on subsector basis. A post hoc analysis on regression values were carried out by using F- circuit and its significance observed. Table 3 will show the sector wise regression result of CCC on various profitability measures.

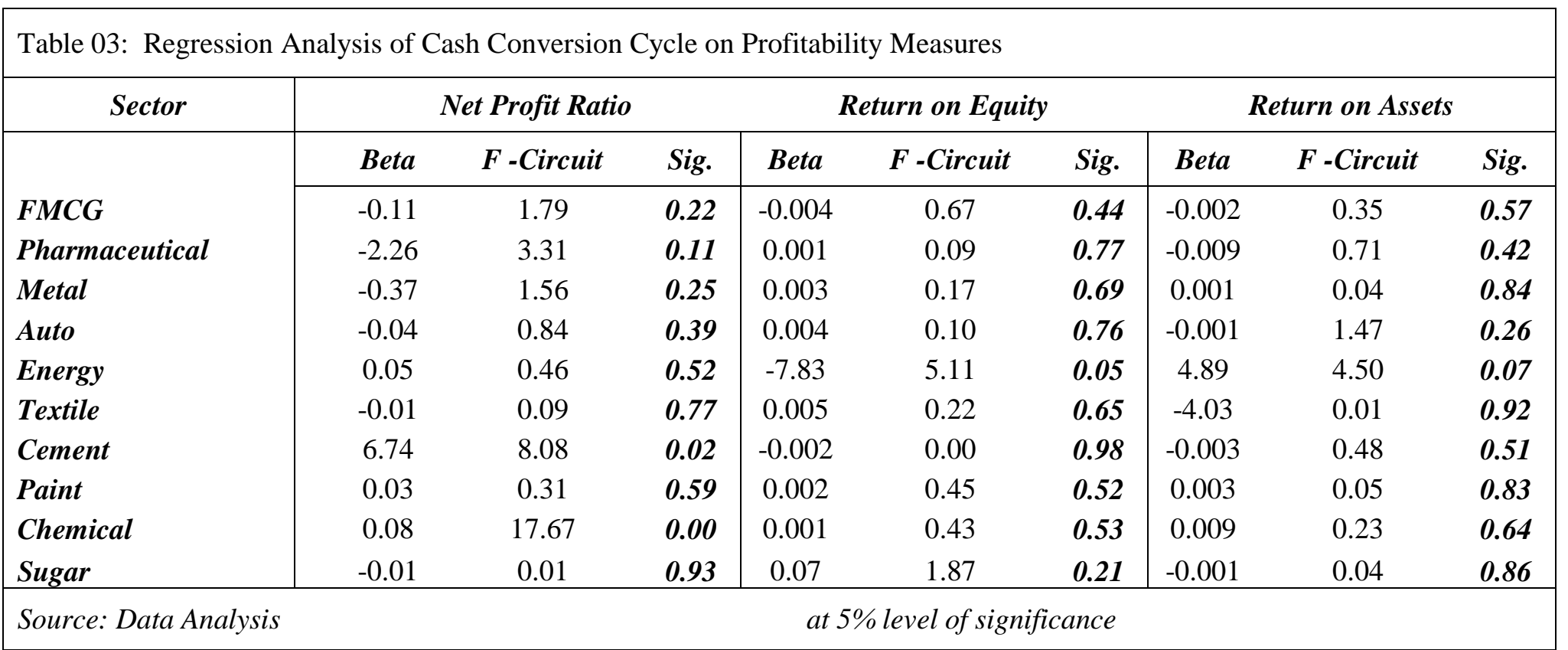


The regression results of CCC on NPR shows that majority of the subsectors possessing a negative relation. Only chemical, paint, cement and energy sectors reported positive regression values of $0.08,0.03,6.74$ and 0.05 respectively. Out of which cement industry exhibits the highest value of 6.74. It signals that if CCC varied by 100 times then the net profit ratio of cement industry will change 674 times. Further F-test shows that out of the sampled industries; only the regression result of two sectors viz. cement and chemical are statistically significant at $5 \%$ level of significance (where $p$ value of 0.02 and 0.00 obtained respectively). As the obtained $p$ values are very much within 0.05 ; statistically signifies the regression result. From subsector wise analysis we can conclude that the obtained regression values pertaining to CCC on NPR is significant only with cement and chemical industries. On the other hand the regression results of $\mathrm{CCC}$ on ROE and CCC on ROA; the obtained values very close to zero line. Further the F test result concludes that the above relation is not statistically significant at $5 \%$ level of significance. Because the p- values obtained are much higher than that of the 0.05 . Thereby it can be concluded that while conducting subsector wise analysis the CCC does not have any significant influence on various profitability measures. (HI: null hypotheses accepted).

The subsector wise impacts of NTC on various profitability measures examined by using regression model and further post hoc analysis of regression results were carryout. The detailed study results are presented on table 4 .

While observing the impact of NTC on various profitability measures; the beta is fluctuating across various sectors. After having a post hoc observation on the above regression values with F- circuit, it can easily say that the above regression results are not statistically significant at $5 \%$ level of significance (as obtained $\mathrm{p}$ values are higher than 0.05). Hence, it can be inferred that NTC cannot make any significant difference on profitability (H2: null hypothesis is accepted). 


\begin{tabular}{|c|c|c|c|c|c|c|c|c|c|}
\hline \multirow[t]{2}{*}{ Sector } & \multicolumn{3}{|c|}{ Net Profit Ratio } & \multicolumn{3}{|c|}{ Return on Equity } & \multicolumn{3}{|c|}{ Return on Assets } \\
\hline & Beta & F-Circuit & Sig. & Beta & F-Circuit & Sig. & Beta & F-Circuit & Sig. \\
\hline$F M C G$ & -3.98 & 1.44 & 0.26 & -0.23 & 1.35 & 0.28 & -0.17 & 1.54 & 0.25 \\
\hline Pharmaceutical & 1772.86 & 0.19 & 0.67 & -7.54 & 4.09 & 0.08 & -2.52 & 0.60 & 0.46 \\
\hline Metal & 3468.08 & 1.11 & 0.32 & -0.06 & 0.00 & 0.95 & 0.14 & 0.03 & 0.86 \\
\hline Auto & -1.44 & 0.08 & 0.78 & -0.01 & 0.00 & 0.96 & -0.08 & 0.43 & 0.53 \\
\hline Energy & 0.00 & 0.33 & 0.58 & -0.09 & 1.65 & 0.23 & -0.04 & 0.80 & 0.40 \\
\hline Textile & 830.02 & 1.68 & 0.23 & -2.49 & 0.87 & 0.38 & 0.70 & 0.47 & 0.51 \\
\hline Cement & 726.97 & 0.02 & 0.89 & 1.17 & 0.80 & 0.40 & 0.22 & 0.11 & 0.75 \\
\hline Paint & -2.05 & 0.06 & 0.81 & 0.18 & 0.15 & 0.71 & -0.03 & 0.01 & 0.92 \\
\hline Chemical & 371.84 & 0.15 & 0.70 & -8.09 & 1.35 & 0.28 & -5.97 & 1.35 & 0.28 \\
\hline Sugar & -37.58 & 0.09 & 0.77 & -12.00 & 0.02 & 0.89 & -0.32 & 0.10 & 0.76 \\
\hline \multicolumn{4}{|c|}{ Source: Data Analysis } & \multicolumn{3}{|c|}{ at $5 \%$ level of significance } & & & \\
\hline
\end{tabular}

\section{Impact of Operating Cycle at Various Phases of the Economy}

The entire study period was grouped as pre-recession phase, recession phase and post-recession phase for measuring the impact of operating cycle on profitability during various economic phases. Here data from the FY 2005-06 to FY 2007-08 were grouped under pre- recession period, the financial data from FY 2008-09 to FY 2009-10 were classified under the title of recession and data from FY 2010-11 onwards were pooled under post-recession heading. Regression analysis was carried out on the whole sample to derive the situation prevalent in various economic phases. 


\begin{tabular}{|c|c|c|c|c|c|c|c|c|c|}
\hline & \multicolumn{3}{|c|}{ NPR } & \multicolumn{3}{|c|}{ ROE } & \multicolumn{3}{|c|}{ ROA } \\
\hline & $\begin{array}{c}\text { Post- } \\
\text { Recession }\end{array}$ & Recession & $\begin{array}{c}\text { Pre- } \\
\text { Recession }\end{array}$ & $\begin{array}{c}\text { Post- } \\
\text { Recession }\end{array}$ & Recession & $\begin{array}{c}\text { Pre- } \\
\text { Recession }\end{array}$ & $\begin{array}{c}\text { Post- } \\
\text { Recession }\end{array}$ & Recession & $\begin{array}{c}\text { Pre- } \\
\text { Recession }\end{array}$ \\
\hline Beta & -0.31 & 0.09 & -0.14 & 0.002 & 0.003 & 0.003 & 0.007 & 0.004 & 0.005 \\
\hline F-Circuit & 3.18 & 1.86 & 116.21 & 0.08 & 0.05 & 0.06 & 0.29 & 0.00 & 0.17 \\
\hline Sig. & 0.11 & 0.21 & 0.00 & 0.79 & 0.83 & 0.82 & 0.61 & 0.96 & 0.69 \\
\hline \multicolumn{4}{|c|}{ Source: Data Analysis } & \multicolumn{3}{|c|}{ at $5 \%$ level of significance } & & & \\
\hline
\end{tabular}

The regression analysis results were exhibited in table 5. While examining the impact of CCC on NPR; negative beta values of -0.31 and -0.14 were respectively obtained in pre-recession and post-recession phases. It signals that the length of CCC and profitability is moving on an opposite direction. And during recession a positive beta of 0.09 was obtained. It means that the cyclical length can influence 0.09 times on profitability during recession. At the same time F-circuit results signifies the beta value of pre-recession period only with $\mathrm{p}$ value of 0.00 at $95 \%$ confidence level. It refers that during pre-recession period cash conversion cycle had a significant negative influence on NPR. While examining CCC on ROE and ROA; the test results produced a beta value very close to the zero marks. But the inferential results of F-circuit do not signifying the above findings as p values obtained are much higher than of 0.05 at $5 \%$ level of significance. Finally it can be inferred that the impact of working capital on profitability was unvarying irrespective of the economic cycle (H3: null hypothesis is accepted). The study results very much agreeing with the argument of Baveld (2012) as the firm need not change their working capital policy in accordance with the economic situations. 


\section{Findings}

The results of the study explicate the real influence of various working capitals metric on profitability with respect to manufacturing sector in Indian economy. With a close scrutiny on descriptive statistical measures signals that majority of the firms in manufacturing sector are having a negative cash conversion cycle. The average CCC for the whole sample panel set was very close to -108 days. The negative CCC arises either on account of liberal credit policy of the supplier or by way of stringent credit policy by the firm. These findings agree with the study results of Pangrahi (2013) where negative CCC obtained for the study conducted. While having a close examination on sub- sector wise; it came to discern that CCC of metal and energy sector are only possessing negative values. Obviously we can say that the metal and energy companies are getting lenient credit from their suppliers; at the same time they are very particular in collecting dues from their debtor and are very strong in encashing inventories. The average collection period for the whole samples were very close to 107 days and the inventory conversion period was around 137 days. Interestingly the average payable period for the entire data set is 287 days. The above statistics again strongly pointing towards suppliers indulgent credit policy. But lenient policy by suppliers cannot be considered firms strength.

The correlation test results monitor the relationship between working capital standards on profitability for the entire panel set. The results points out that CCC possess a negative correlation with $\mathrm{ROE}$ at the same time positively correlated to NPR. If CCC is prolonged the companies can enhance their revenue by way for maximizing credit sales. Normally profit can be maximized through sales proceeds. So with respect this positive correlation result of 0.090 between CCC and NPR signifies that CCC can influence profitability. A negative correlation result of -0.120 was obtained between CCC and ROE. This shows that if CCC is lengthy that much delay will happen to recover return on investment. From this angle a negative relationship will be usually preferred. With respect to another working capital measure of NTC on profitability; NTC had a positive relationship with ROE and ROA but have a negative correlation with NPR. However the correlation tests results pointing some positive relation between working capital metrics and profitability measures. This will add to the existing literature by supporting the findings of Deloof (2003), Gill (2010), Mohammed (2010), Quazi (2011), Afeef (2011), Sharma (2011) and Quayyam (2011). But these findings are disagreeing with the view point of Rahman (2011), Bagchi (2012), Ray (2012) and Napompech (2012).

A sub sector wise regression analysis was performed to find extend of impact of CCC and NTC on various profitability measures. The result shows that CCC has a positive influence on NPR of chemical and cement industries with beta values of 6.74 and 
0.08. Further the above regression results signify with $\mathrm{p}$ values of 0.02 and 0.00 respectively. But with respect to other subsectors the F-circuit results not signifies any relations ( $\mathrm{p}$ values are much higher than 0.05 ). The sector wise result of net trade cycle to profitability measures shows that the obtained beta values are not statistically significant. For the whole sample F- circuit does not signifies any relation as the probability value obtained are much higher than that of 0.05 .

It was a quite interesting question that how operating cycle can influence profitability measures during various economic phases. The post hoc analysis of regression results signifies that CCC negatively influenced NPR only on pre-recession phase. The beta value -0.14 can be inferred that if the CCC is lengthy it will adversely affect net profit (obtained $\mathrm{p}$ value $0.00<0.05$ ). In all other phases the F-Circuit did not signifies the beta coefficient. In other words we can conclude that there is no significant difference between CCC and various profitability measures during distinct phase of economy. This result advises that the firm does not want to change their working capital policies looking at economic phases. This argument agree with the study results of Baveld (2012) but contrary to the early literatures of Kesimli (2011), Duggal (2012), Singhania (2014), VU and Phan (2016). Majority of the literature argues that firms will have to reframe their working capital policies based on economic situation. But outcome of this study strongly points that a stable policy has to be framed by giving emphasis on profitability aspect.

\section{Conclusion}

The results and discussions of this research paper will really help the policy makers to look in to the influence of working capital on profitability. The initial objective of the study was to observe how various working capital metrics influencing profitability of the firms. The interesting fact observed is that DIO is negatively correlated to profitability whereas DSO and DPO exhibits a positive relation. It is meant that the firms will have to reduce their inventory holding period. Positive DPO points that availing a lengthy credit period from suppliers can positively influence profit. At the same time a positive correlation between DSO and profitability encourages the firms to follow a lenient credit policy to maximize their sales. One major metric CCC has a positive relation with NPR but which possess a negative relation with ROE. NPR usually tagged with sales and net sales can be increased only with a lengthy CCC. A negative relation was obtained between $\mathrm{CCC}$ and ROE. This signals that return to the investors will be delayed if $\mathrm{CCC}$ is lengthy. The above results signal that working capital management can have a direct bearing on profitability. The second objective was to investigate how CCC and NTC influencing profitability of various subsectors. The result denotes that CCC can positively influence the profitability of cement and chemical industries only. This work is also aimed to look 
into the influence of working capital on profitability during various economic phases. The study result does not produce any strong evidence on speckled influence between working capital and profitability during various states of the economy. However Fcircuit result signifies that of $\mathrm{CCC}$ can negatively influence the profitability during pre-recession stage.

\section{References}

Abuzayed,B. (2012). Working capital management and firms' performance in emerging markets: the case of Jordan, International Journal of Managerial Finance, Vol. 8 (2), pp. $155-179$.

Afeef,M. (2011). Analyzing the Impact of Working Capital Management on the Profitability of SME's in Pakistan, International Journal of Business and Social Science, Vol. 2(22), pp. 173-183.

Agha, H. (2014).Impact of Working Capital Management on Profitability, European Scientific Journal, Vol.10 (1), pp.374-381.

Akoto, R.K, Vitor, D.A. and Angmor, P.L. (2013). Working capital management and profitability: Evidence from Ghanaian listed Manufacturing firms, Journal of Economics and International Finance, Vol.5 (9), pp. 373-379.

Aregbeyen, O. (2013).the effects of working capital management on the profitability of Nigerian manufacturing firms, Journal of Business Economics and Management, Vol.14(3), pp. 520-534.

Bagchi,B. and Khamrui, B. (2012). Relationship between Working Capital Management and Profitability: A Study of Selected FMCG Companies in India, Business and Economics Journal, Vo.1 (1), pp.1-11.

Baveld, M.B. (2012). Impact of Working Capital Management on the Profitability of Public Listed Firms in the Netherlands during the Financial Crisis. University of Twente (Thesis). February 2012.

Bieniasz1, A. and Gołaś, Z. (2011). The Influence of Working Capital Management on the Food Industry Enterprises Profitability, Contemporary Economics, Vol.5 (4), pp. 6881.

Ching,H.Y and Novazzi, A. (2011).Relationship between working capital management and profitability in Brazilian Listed Companies, Journal of Global Business Economics, Vol.3(1), pp. 74-86.

Deloof,M. (2003). Does Working capital management affects profitability of Belgian firms? Journal of Business Finance \& Accounting, Vol. 30(3\&4), pp. 573-587.

Duggal, R and Budden, C.M. (2012). The Effects of the Great Recession on Corporate Working Capital Management Practices. International Business and Economic Research Journal. Vol. 11(7), pp. 753-756. 
Enqvist, J.,Graham, M. and Nikkinen, J. (2014).The impact of working capital management on firm profitability in different business cycles: Evidence from Finland, Research in International Business and Finance, Vol. 32(1), pp. 36-49.

FICCI Report (2014). India Manufacturing Barometer 2014 turning the corner, prepared by $P W C$.

Gill, A., Biger, N. and Mathur, N. (2010). The Relationship Between Working Capital Management And Profitability: Evidence from the United States, Business and Economics Journal, Vol.10 (1), pp.1-9.

Haron, R. and Norman,N.M. (2015). Determinants of working capital management before, during and after the global financial crisis of 2008: evidence from Malaysia. Asia Pacific Conference on Business and Social Sciences 2015, Kuala Lumpur. pp. 331340.

Ikepfan, Aileman, O. and Folashade, O. (2014). Working Capital Management and Profitability of the Manufacturing Sector: An Empirical Investigation of Nestle Nigeria PLC and Cadbury Nigeria PLC. Global Journal of Management and Business Research. Vol. 16(4), pp. 20-27.

Joyce, N., Daniel,W. and Josphat, K. (2012). Influence of Working Capital Management on Profitability of Non Deposit-Taking Microfinance Institutions in Kenya: A Survey of Non Deposit-Taking MFIs in Nakuru East Sub-County, International Journal of Science and Research, Vol. 3(!0),pp.1750-1756.

Kesimli, I.G and Gunay, S.G. (2011). The impact of the global economic crisis on working capital of real sector in Turkey. BEH - Business and Economic Horizons, Vol. 4(1). pp. 52-69.

Khanqah, T., Khosroshahi, M.A. and Ebrati, M. R.(2012).An Investigation of the Association between Working Capital Management and Corporate Performance , International Journal of Management and Business Research, Vol. 2(3), pp. 203-218.

Knauer, T. and Wohrmann, A. (2013).Working Capital Management and Firms Profitability, Journal of Management Control, Vo.24(1),pp. 77-87.

Makori, D.M. and Jagongo, A. (2013).Working Capital Management and Firm Profitability: Empirical Evidence from Manufacturing and Construction Firms Listed on Nairobi Securities Exchange, Kenya, International Journal of Accounting and Taxation, Vol.1(1), pp. 1-14.

Mohamad, N.E.A.B and Saad, N.B.M. (2010).Working Capital Management: The Effect of Market Valuation and Profitability in Malaysia, International Journal of Business and Management, Vol. 5(11), pp. 140-147.

Napompech, K. ( 2012).Effects of Working Capital Management on the Profitability of Thai Listed Firms, International Journal of Trade, Economics and Finance, Vol. 3(3), pp. 227-232. 
Nasrin, Y. and Zeinab,A.(2016).Impact of Working Capital Management on Firms Profitability in Business Cycles. Journal of Accounting Knowledge, Vol. 6(23). pp. 147-171.

Nizioki,P.M et.al. (2013).Management of working capital and its effect on profitability of manufacturing companies listed on Nairobi securities exchange (NSE), Kenya, International Journal of Business and Finance Management Research', Vol.1(1),pp35-42.

Panigrahi, A.K. (2013). Cash conversion cycle and firms' profitability - a study of cement manufacturing companies of India. International Journal of Current Research .Vol. 5 (6), pp.1484-1488.

Qasi,A.H. et.al. (2011). Impact of working capital on firms' profitability, African Journal of Business Management, Vol. 5(27), pp. 11005-11010.

Quayyam, S.T. (2011).Effects of Working Capital Management and Liquidity: Evidence from the Cement Industry of Bangladesh, Journal of Business and Technology, Vol.6 (1), pp. 37-48.

Rahman,M.M. (2011).Working Capital Management and Profitability: A Study on Textiles Industry, ASA University Review, Vol. 5(1), pp. 15-132.

Ray,S. (2012).Evaluating the Impact of Working Capital Management Components on Corporate Profitability: Evidence from Indian Manufacturing Firms, International Journal of Economic Practices and Theories, Vol. 2(3), pp. 12- 136.

Singhania, M., Sharma, N. and Rohit, Y. (2014). Working capital management and profitability: evidence from Indian manufacturing companies. DECISION, Vol. 41(3), pp. 313-326.

Sharma, A.K and Kumar,S. (2011) 'Effects of Working Capital Management on Profitability: Empirical Evidence from India', Global Business Review, Vol. 12(1), pp. 159-173.

VU, M.C. and Phan, T.T. (2016). Working Capital Management and firm's profitability during the period of financial crisis: an empirical study in emerging country of Vietnam. Advances in Social Science Research Journal, Vol. 3(3), pp. 156-168.

Vural,G., Okmen,A.G. and Cetenak, E.H. (2012). Effects of Working Capital Management on Firm's Performance: Evidence from Turkey, International Journal of Economics and Financial Issues, Vol. 2(4), pp. 488-495.

Wasiuzzaman,S. and Arumugam, V.C. (2013). Determinants of Working Capital Investment: A Study of Malaysian Public Listed Firms. Australasian Accounting, Business and Finance Journal, Vol. 7(2), pp.63-83.

\section{Annexure 1}




\begin{tabular}{|l|l|r|l|}
\hline \multicolumn{3}{|c|}{ List of Sampled Companies } \\
\hline \multicolumn{2}{|c|}{ Company } & \multicolumn{2}{c|}{ Company } \\
\hline 1 & Britannia Industries Ltd. & 28 & Exide Industries Ltd. \\
\hline 2 & Colgate Palmolive (India) Ltd. & 29 & Hero MotoCorp Ltd. \\
\hline 3 & Dabur India Ltd. & 30 & MRF Ltd. \\
\hline 4 & Emami Ltd. & 31 & Mahindra \& Mahindra Ltd. \\
\hline 5 & Godrej Consumer Products Ltd. & 32 & Maruti Suzuki India Ltd. \\
\hline 6 & Hindustan Unilever Ltd. & 33 & Motherson Sumi Systems Ltd. \\
\hline 7 & I T C Ltd. & 34 & TVS Motor Company Ltd. \\
\hline 8 & Marico Ltd. & 35 & Tata Motors Ltd. \\
\hline 9 & Procter \& Gamble Hygiene \& Health & 36 & $\begin{array}{l}\text { Bharat Petroleum Corporation } \\
\text { Care Ltd. }\end{array}$ \\
\hline 10 & Tata Global Beverages Ltd. & 37 & Cairn India Ltd. \\
\hline 11 & United Breweries Ltd. & 38 & GAIL (India) Ltd. \\
\hline 12 & Aurobindo Pharma Ltd. & 39 & $\begin{array}{l}\text { Hindustan Petroleum } \\
\text { Corporation Ltd. }\end{array}$ \\
\hline 13 & Cadila Healthcare Ltd. & 40 & Indian Oil Corporation Ltd. \\
\hline 14 & Cipla Ltd. & 41 & NTPC Ltd. \\
\hline 15 & Divi's Laboratories Ltd. & 42 & Oil \& Natural Gas \\
\hline 16 & Dr. Reddy's Laboratories Ltd. & 43 & $\begin{array}{l}\text { Power Grid Corporation of } \\
\text { India Ltd. }\end{array}$ \\
\hline 17 & Glaxosmithkline Pharmaceuticals & 44 & Reliance Industries Ltd. \\
\hline 18 & Ltd. & 45 & Tata Power Co. Ltd. \\
\hline 19 & Lupin Ltd. & 46 & LAMBODHARA \\
\hline 20 & Piramal Enterprises Ltd. & 47 & Morarjee Textiles Limited \\
\hline 21 & Sun Pharmaceutical Industries Ltd. & 48 & $\begin{array}{l}\text { Soma Textiles \& Industries } \\
\text { Limited }\end{array}$ \\
\hline 22 & Coal India Ltd. & 49 & Vardhman Textiles Limited \\
\hline 23 & Hindalco Industries Ltd. & 50 & $\begin{array}{l}\text { Century Textiles \& Industries } \\
\text { Limited }\end{array}$ \\
\hline 24 & JSW Steel Ltd. & 51 & Gangotri Textiles Limited \\
\hline 25 & Jindal Steel \& Power Ltd. & 52 & $\begin{array}{l}\text { Integra Garments and Textiles } \\
\text { Limited }\end{array}$ \\
\hline 26 & NMDC Ltd. & 53 & GTN Textiles Limited \\
\hline 27 & National Aluminium Co. Ltd. & Limited \\
\hline 55 & Steel Authority of India Ltd. & & \\
\hline
\end{tabular}




\begin{tabular}{|l|l|c|l|}
56 & Tata Steel Ltd. & 79 & $\begin{array}{l}\text { Hanung Toys and Textiles } \\
\text { Limited }\end{array}$ \\
\hline 57 & Amara Raja Batteries Ltd. & 80 & Nepc Textiles Limited \\
\hline 58 & Apollo Tyres Ltd. & 81 & The India Cements Limited \\
\hline 59 & Ashok Leyland Ltd. & 82 & JK Cement Limited \\
\hline 60 & Bajaj Auto Ltd. & 83 & Mangalam Cement Limited \\
\hline 61 & Bosch Ltd. & 84 & $\begin{array}{l}\text { Somani Cement Company } \\
\text { Limited }\end{array}$ \\
\hline 62 & Eicher Motors Ltd. & 85 & JK Lakshmi Cement Limited \\
\hline 63 & ITD Cementation India Limited & 86 & $\begin{array}{l}\text { Thirumalai Chemicals } \\
\text { Limited }\end{array}$ \\
\hline 64 & $\begin{array}{l}\text { Kakatiya Cement Sugar \& Industries } \\
\text { Limited }\end{array}$ & 87 & $\begin{array}{l}\text { Alkyl Amines Chemicals } \\
\text { Limited }\end{array}$ \\
\hline 65 & UltraTech Cement Limited & 88 & Fineotex Chemicals \\
\hline 66 & The Ramco Cements Limited & 89 & $\begin{array}{l}\text { TECIL Chemicals and Hydro } \\
\text { Power Limited }\end{array}$ \\
\hline 67 & Andhra Cements Limited & 90 & Bodal Chemicals Limited \\
\hline 68 & Sagar Cements Limited & 91 & $\begin{array}{l}\text { Himadri Chemicals and } \\
\text { Industries Limited }\end{array}$ \\
\hline 69 & Burnpur Cement Limited & 92 & $\begin{array}{l}\text { Gujarat Narmada Valley } \\
\text { Fertilizers and Chem }\end{array}$ \\
\hline 70 & Ambuja Cements Limited & 93 & $\begin{array}{l}\text { Kothari Petrochemicals } \\
\text { Limited }\end{array}$ \\
\hline 71 & Barak Valley Cements Limited & 94 & Dalmia Sugar \\
\hline 72 & HeidelbergCement India Limited & 95 & $\begin{array}{l}\text { Bajaj Hindusthan Sugar } \\
\text { Limited }\end{array}$ \\
\hline 73 & Kansai Nerolac Paints Limited & 96 & Uttam Sugar Mills Limited \\
\hline 74 & Asian Paints Limited & 97 & Sakthi Sugars Limited \\
\hline 75 & Shalimar Paints Limited & 98 & $\begin{array}{l}\text { Bannari Amman Sugars } \\
\text { Limited }\end{array}$ \\
\hline 76 & Berger Paints (I) Limited & 99 & Kothari Sugars \\
\hline 77 & $\begin{array}{l}\text { Dishman Pharmaceuticals and } \\
\text { Chemicals Ltd }\end{array}$ & $\begin{array}{l}\text { Dwarikesh Sugar Industries } \\
\text { Limited }\end{array}$ \\
\hline
\end{tabular}

